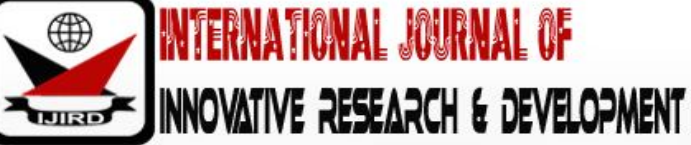

ISSN 2278 - 0211 (Online)

\section{Motivation as a Mode to Sustain Female Students' Participation in ICT Practical Lessons}

\begin{tabular}{|c|}
\hline Benjamin Baiden \\
ICT Tutor, Department of Mathematics and ICT, St. Joseph's College of Education, Ghana \\
Victor King Anyanful \\
ICT Tutor, Department of Mathematics and ICT, OLA College of Education, Ghana \\
Victor Dannyansah \\
BCT Tutor, Department of Mathematics and ICT, Atebubu College of Education, Ghana \\
Bryce Yaw Kesse \\
ICT Tutor, Department of Mathematics and ICT, Berekum College of Education, Ghana
\end{tabular}

\begin{abstract}
Motivation is key in every endeavor. Young Females who are the hope of the society cannot be neglected in this information age. One feels dejected to see level two hundred (200) female students of St. Joseph's and Berekum Colleges of Education not involving themselves in the practical activities in ICT. These students only show interest in the theory aspect of the subject (ICT), but the ICT syllabus for Colleges of Education aims at offering basic knowledge and skills to students (Ministry of Education Science and Sports, 2004). It is against this background that this research was conducted to ensure female students involve themselves and use ICT tools well in practical lessons. The researchers made use of quantitative research methodology together with random and stratified sampling techniques to collect valid data on the problem. Notwithstanding, questionnaire methodology was employed in gathering relevant data from the research population. Results from the study revealed that students reported certain things teachers do to reduce their interest in class. Teachers also reported that they deliver lessons without appropriate TLMs. Based on the findings; it was recommended that students should be given career guidance and counselling on the relevance of the subject through career conferences and conventions. In doing this, role models should be used. It was also recommended that school authorities must ensure provision of adequate ICT tools to facilitate the teaching and learning of ICT.
\end{abstract}

Keywords: Female participation, ICT practical, information and communication technology, female education, motivation

\section{Introduction}

Information and Communication Technology as tools within the school environment include use for school administration and management, teaching and learning of ICT related skills for enhancing the presentation of classroom work, teaching/ learning repetitive tasks, teaching/ learning intellectual, thinking and problem-solving skills, stimulating creativity and imagination, for research by teachers and students and as communication tool by teachers and students (Derbyshire, 2003).

The field of education has been affected by ICTs, which have undoubtedly affected teaching and research (Yusuf, 2005). A great deal of research has proven the benefits of ICT in improving quality of education (AL-Ansari, 2006). As a result of this, developed nations have integrated ICT into their educational system.

Touching the impact of new technologies on the workplace and everyday life, recent educational institutions try to streamline their educational programs and classroom facilities in order to reduce the teaching and learning technology gap between developed and the developing countries. This reformation process is providing learners with knowledge of specific subject areas, to promote meaningful learning and to enhance professional productivity (Tomei, 2005).

African countries in general are increasing and significantly growing. However, while there is a great deal of knowledge about how ICTs are being incorporated and used in both high schools and colleges in developed countries, there is not enough information on how ICTs are being embraced by teachers and students in Ghanaian schools. There is also a supposition that there are wide gaps in the use of ICTs between rural and urban schools (Aduwa-Ogiegbaen \& Iyamu, 2005). The instructor who uses ICT in the lessons is perceived to be the essential factor in the improvement process (Veen, 1995). The teacher plays a critical role in organising and managing the learning environment (Smeets\&Mooij, 2000). The learner usually decides what activities have to be carried out in the learning process (Jonassen, 1993).

\subsection{Research Question}

The research question used for this study is as follows: 


\section{- How can motivation help sustain female students' participation in ICT practical lessons?}

\subsection{Reviewed Materials and Methods}

\subsubsection{Using Motivation to Sustain Female Students' Participation in ICT Practical Lessons}

Motivation refers to "the reasons underlying behaviour" (Guay, 2010, p712). Paraphrasing Gredler, Broussard and Garrison (2004) broadly define motivation as "the attribute that moves us to do or not to do something".

Eisenberg (2010) defines motivation as the act of giving somebody a reason or incentive to do something. Eccles and Wigfield (2002) further described motivation as the cause of an organism's behaviour, or the reason that an organism carries out some activity which involves both conscious and unconscious drives. Elliot (2000) defined motivation as "an internal state that arouses us to action, pushes us in particular directions, and keeps us engaging in certain activities".

Critical examination of the above definitions of motivation indicates that people move to a direction and perform activities to their best if they are motivated. According to Banahene (2009), motivation is the internal condition that activates behaviour and gives it direction; energizes and directs goal-oriented behaviour. Therefore, students of both lower and higher levels of educational ladder are mostly expected to be motivated in variety of ways to arouse and sustain their interests in a particular activity, subject, and any other aspect of the curriculum.

Students need to be motivated both intrinsically and extrinsically about the subject of study. To add to this, Conner (2007), educational psychologist stated in Ageless Learner that "the way we feel about a program influences our commitment to it. If we feel secured, respected, esteemed, and empowered, we're likely to make a strong effort. If we feel threatened, anxious, hostile, or demeaned, we're likely to resist".

Conner again stated that "behaviour can change as a result of extrinsic motivators such as incentives, rewards, and punishments. Behaviourists advocate influencing behaviour through the systematic adjustments of stimulus-response reinforcements". Conner (2007) is of the view that teaching and learning process should be designed to make the learner feel secured and empowered to undertake any activity in the school programme. The researchers of this study is of the view that if learners are made aware of the career opportunities and their benefits associated with a particular discipline, they are likely to be motivated.

Banahene (2009) further described the types of motivation as intrinsic and extrinsic as follows:

Intrinsic motivation comes from rewards inherent to a task or activity itself - the enjoyment of a puzzle or the love of playing basketball, for example. One is said to be intrinsically motivated when engaging in an activity "with no apparent reward except for the activity itself". Research has found that it is usually associated with high educational achievement and enjoyment by students.

Students are likely to be intrinsically motivated if they: attribute their educational results to internal factors that they can control (e.g. the amount of effort they put in), believe they can be effective agents in reaching desired goals (i.e. the results are not determined by luck), are interested in mastering a topic, rather than just rote-learning to achieve good grades.

Extrinsic motivation comes from outside of the performer. Money is the most obvious example, but coercion and threat of punishment are also common extrinsic motivations. In sports, the crowd may cheer the performer on, and this motivates him or her to do well. Trophies are also extrinsic incentives. Competition is often extrinsic because it encourages the performer to win and beat others, not to enjoy the intrinsic rewards of the activity.

The above literature indicates that application of both intrinsic and extrinsic motivation in teaching is very necessary since it is likely to contribute to achieving the objectives in a lesson if learners are well motivated. Adentwi (2009) however, stated that "extrinsic incentives sometimes can weaken the motivation as well. In one classic study done by Green and Lepper (2004), children who were lavishly rewarded for drawing with felt-tip pens later showed little interest in playing with the pens again".

However, in reaction to the above reviewed literature, all the researchers focused on just the two basic types of motivation (intrinsic and extrinsic) without considering the organismic sources of the said types of motivation to make teaching and learning process lively which the present researchers want to bring onboard as follows:

Motivational theorists of the early 20th century searched for general principles of behavior. Theories of the period focused primarily on the motivations triggered by organismic physiological drives or needs such as food, sleep, procreation, and security Hull (1943). Organisms were perceived to be motivated to behave in ways that replenish biological deficits and secure survival. Because behavior that aims to satisfy a physiological deficit is done in order to achieve a goal and not for its own sake, it represents a type of extrinsic motivation.

Taking a different approach to motivation, behaviorist psychologists (Skinner, 1953) argued that behavior can be explained by the organisms' motivation to approach pleasant and desirable outcomes and to avoid unpleasant and undesirable outcomes. Also, the reviewed literature on motivation never highlighted on pleasant and unpleasant desirable outcomes which the present researchers sees as incomplete to make it complete in its full sense. Pleasant outcomes constitute a reward, and enhance the chance that a behavior will recur, whereas unpleasant outcomes constitute a punishment and reduce the chance that a behavior will recur. Behaviorist psychologists argued that human (and animal) behavior can be explained by the various rewards and punishments in the environment. Thus, from a behaviorist perspective, all motivation is extrinsic. However, during the middle of the 20th century, several theorists challenged the mechanistic models of the drive and behaviorist perspectives. These theorists relied on observations indicating that sometimes people (and animals) engage in behavior without an apparent reward. This engagement is seen to manifest universally early in life in children's exploration and play (Berlyne, 1960). But it also appears among older people who engage in games and hobbies. These observations seem to suggest that such engagement is inherently enjoyable and 
satisfying. This type of motivation is contrasted with behavior propelled by "extrinsic" forces, and is labeled "intrinsic" motivation (Hunt, 1965).

\subsubsection{Herzberg's Two-Factor Theory}

Frederick Herzberg (1964) two-factor theory, also known as intrinsic/ extrinsic motivation, concludes that certain factors in the workplace result in job satisfaction, but if absent, lead to dissatisfaction. Herzberg distinguished between motivators and hygiene factors as follows.

Motivators; (e.g. challenging work, recognition, responsibility) which give positive satisfaction, Hygiene factors; (e.g. status, job security, salary and fringe benefits) that domotivate if present, but, if absent, result in demotivation.

\subsubsection{Self-Determination Theory (SDT)}

Deci and Ryan (1985) developed Self-determination theory which focuses on the importance of intrinsic motivation in driving human behaviour. Like Maslow's hierarchical theory and others that built on it, SDT posits a natural tendency toward growth and development. Unlike these other theories, however, SDT does not include any sort of "autopilot" for achievement, but instead requires active encouragement

from the environment. The primary factors that encourage motivation and development are autonomy, competence feedback, and relatedness.

\subsubsection{Alderfer's ERG Theory}

Clayton Alderfer (1977), expanding on Maslow's hierarchy of needs, created the ERG theory (existence, relatedness and growth). Physiological and safety, the lowerorder needs, are placed in the existence category, while love and self-esteem needs are placed in the relatedness category. The growth category contains ourself-actualization and selfesteem needs.

The reviewed literature researchers only talked about few theoretical explanations of both intrinsic and extrinsic motivation which are not complete in the full sense of motivation in teaching and learning process whereby the present researchers take delight in unearthing them to make this research work more reliable and accurate. Thus, researchers of yesteryears and today have proposed a variety of theoretical explanations for intrinsic motivation, including characteristics of activities such as novelty and fantasy and biological mechanisms such as play instincts, curiosity, and need for stimulation. In a seminal paper, White (1959) reviewed several of these theoretical explanations and argued for their integration in a motive that developed along evolution, which he termed "effectance" motivation, or need for competence. White argued that this motive propels children to explore their surroundings, manipulate objects, and interact with others in ways that promote mastery of the environment. Unlike physiological needs, which operate on a homeostatic principle - that is, they are aroused when the organism is deficient in a resource, and operate to guide action towards reducing the deficiency- effectance motivation is aroused particularly when no deficiency exists.

Engagement out of effectance motivation does not have a clear end-goal; rather, it is the engagement in the activity itself that elicits positive feelings of efficacy, which constitute an "intrinsic" reward.Taking a different ideological approach, humanistic psychologists of the mid 20th century such as Maslow (1954) and Rogers (1963) challenged the drive and behaviorist perspectives by suggesting the existence of human needs that give rise to intrinsic motivation. Maslow, for example, argued that the physiological and safety needs, which he labeled "deficiency needs," are distinct from self-actualization needs, such as the need to develop talents, achieve comprehension, and fulfill potential, which he labeled "growth" needs. While the former provides the basis for extrinsic types of motivation, the latter provide the basis for intrinsic types of motivation.

At the beginning of the 21st century, many theorists still hold that intrinsic and extrinsic motivations are based on organismic needs. One such comprehensive theoretical framework- self-determination theory (SDT) (Deci\& Ryan, 1985; Ryan \&Deci, 2000)-explicitly asserts that humans are motivated by three basic psychological needs: for competence, relatedness, and autonomy. The need for competence in SDT is what White (1959) called effectance motivation. The need for relatedness refers to people's need to belong and to feel accepted by others. The need for autonomy refers to people's need to feel self-determined- to be the source of their own action (deCharms, 1968). Like physiological needs, these psychological needs are thought to represent necessary nourishment for psychological development and growth. When an individual's three needs are fully satisfied, engagement in action is intrinsically motivated and promotes adaptive development and well-being. On the other hand, when one of the needs is unsatisfied, engagement is likely to be extrinsically motivated and development may be hindered.

\subsection{Application of Motivation in Education}

Motivation is of particular interest to educational psychologists because of the crucial role it plays in students' learning. According to Banahene (2009), motivation in education can have several effects on how students learn and how they behave towards subject matter. These include:

- Direct behaviour towards particular goals

- Lead to increased effort and energy

- Increase initiation of, and persistence in, activities

- Enhance cognitive processing

- Determine what consequences are reinforcing

- Lead to improved performance. 
Because students are not always internally motivated, they sometimes need situated motivation, which is found in environmental conditions that the teacher creates.

Motivation which is important psychological construct affects learning and performance in four ways:

- Motivation increases an individual's energy and activity level. It influences the extent to which an individual is likely to engage in certain activities intensively or half-heartedly.

- Motivation directs an individual towards certain goals. This means that the

choice people make is greatly influenced by motivation.

- Motivation promotes initiation of certain activities and persistence in those activities.

- Motivation affects the learning strategy and cognitive processes an individual employ. It increases the likelihood that people will pay attention to something, study and practice it, and try to learn in a meaningful fashion.

The above concepts of motivation indicate that students, particularly females will only initiate engagement in an activity, persist in such activity to attain success, if they are well motivated. This is illustrated by young female finalists who presented the many advantages of careers in IT and science, providing motivation and mentorship to further develop the skills of women in the ICT sector.

The present researchers are therefore appealing to all teachers and educationists to pay attention to motivation since it is the best way to direct learners towards a particular goal.

Banahene (2007) further cited the self-efficacy theory of Bandura (1990) indicating that "individual success raises their self-efficacy, while failures are particularly likely

to lower their self-efficacy if they occur early in the learning processes". This theory seeks to inform teachers to plan and implement lessons that will ensure students' success in classroom activities. Steps must be taken to minimize failures which are likely to occur especially during the early part of an activity as well as the basic, second cycle and tertiary (College) levels of education.

The basic principles of motivation that are applicable to learning in any situation include:

Environment: The environment can be used to focus student's attention on what needs to be learned. Banahene (2009) suggested here that teachers must create warm and accepting yet business-like atmospheres to promote persistent effort and favourable attitudes toward learning. This strategy will be successful in children and in adults. Interesting visual aids, such as booklets, posters, or practice equipment, motivate learners by capturing their attention and curiosity.

Incentives: Incentives motivate learning. Incentives which include privileges and receiving praise from the instructor are likely to motivate an individual at a particular time. The instructor must therefore determine an incentive that is appropriate at each instance (Weller, 2005).

Internal motivation: This is longer lasting and more self-directive than external motivation, which must be repeatedly reinforced by praise or concrete rewards. Some individuals, particularly children of certain ages and some adults have little capacity for internal motivation and must be guided and reinforced constantly. Caution should be exercised in using external rewards when they are not absolutely necessary (Weller, 2005).

Learning: This is most effective when an individual is ready to learn, that is, when one wants to know something. Sometimes the student's readiness to learn comes with time, and the instructor's role is to encourage its development. If a desired change in behaviour is urgent, the instructor may need to supervise directly to ensure that the desired behaviour occurs. If a student is not ready to learn, he or she may not be reliable in following instructions and therefore must be supervised and have the instructions repeated again and again (Weller, 2005).

Instructional material: Motivation is enhanced by the way in which the instructional material is organized. In general, the best organized material makes the information meaningful to the individual. One method of organization includes relating new tasks to those already known (Weller, 2005).

Weller (2005) concluded by saying that "none of the techniques will produce sustained motivation unless the goals are realistic for the learner. The basic learning principle involved is that success is more predictably motivating than is failure".

It is obvious that Weller has provided comprehensive principles of classroom motivation required to move learners towards the desired goals and activities of a particular discipline. The researchers therefore saw that using these principles in the teaching and learning process will help to fully motivate students thereby ensuring their maximum participation in the classroom, workshop and laboratory activities.

During motivation the instructor or teacher must consider motivational factors and strategies under the instructional period (beginning, during and ending). In this approach, appropriate motivational factors including attitudes, needs, stimulation, affect and reinforcement, and their corresponding strategies must be given at each period within the instructional frame.

Suggestion of some techniques and strategies that teachers can employ in their classroom to make students become motivated are:

- Make students active participants in learning: - students learn best through doing, making, writing, designing, creating and solving.

- Tell students what they need to do to succeed in your course.

- Avoid creating intense competition among students.

- Be enthusiastic about students.

- Vary your teaching methods.

- Give students feedback as quickly as possible.

- Reward success using both positive and negative comments. 
- Avoid demeaning comments.

- Hold high but realistic expectation for your students.

The researchers, upon critical analysis of the comprehensive motivational theories and strategies, saw that if measures are taken to integrate them into the classroom activities, there is the likelihood that female students will commit themselves to every activity that goes on in the classroom.

Even though, the present researchers agree with how the literature reviewed on application of motivation in education by the earlier researchers but on the contrary, they lost focus on models of intrinsic and extrinsic motivation and how they could be applied in education to facilitate harmonious learning which the present researchers have unearthed below.

Whereas organismic needs energize intrinsic and extrinsic motivations, the concept of need in itself is too general to explain engagement in specific behaviors and too vague to be a guide for empirical research (Harter, 1981; Pintrich \& Schunk, 2002). Therefore, during the second half of the 20th century, researchers developed models that described how motivation triggered by needs manifests in intrinsic and extrinsic motivation in specific domains and activities. These models also explained how factors in the environment may shape and affect the type of motivation that people manifest in different domains.

In one important model of intrinsic motivation, Czikzentmihalyi (1990) focused on a phenomenological state of full absorption in an activity, which he labeled "flow." In this pure form of intrinsic motivation, "Concentration is so intense that there is no attention left over to think about anything irrelevant, or to worry about problems. Self-consciousness disappears, and the sense of time becomes distorted". Czikzentmihalyi interviewed professional artists, athletes, rock climbers, and chess players about their flow experiences and concluded that flow is most likely to be experienced when there are clear goals to be achieved and there is an optimal balance between the challenge posed by the activity and the person's level of skill. In addition, flow is experienced when there is immediate feedback on one's action and when the person feels a sense of control over the environment. According to Czikzentmihalyi, flow experiences promote further intrinsic motivation as well as skills in a domain.

Since experiences of flow are rewarding, people are motivated to replicate the experience. Through engagement in challenging activities, skills develop and the person is motivated to seek more difficult challenges in the domain. Thus, growth of competencies and intrinsic motivation in the domain facilitate each other. In a different program of research, Harter $(1981,1992)$ developed a model detailing how intrinsic motivation in different domains is shaped by experiences of success and failure as well as reinforcement from significant others. According to Harter, effective motivation leads children to seek challenges, learn out of curiosity and for the experience of pleasure, and rely on themselves for a sense of success. When curiosity, independence, and exploration result with experiences of mastery and meet the approval and encouragement of parents or teachers, children experience pleasure, feel competent and in control of their environment, and have stronger intrinsic motivation for the domain or activity. However, when such engagement results with experiences of failure and meets disapproval by others, children feel anxious, perceive themselves to have low competence and control, and have lower intrinsic motivation. According to Harter, when parents and teachers demand compliance and employ extrinsic rewards and punishments, children develop extrinsic motivation for activities and domains.

In yet another elaborate model, self-determination theorists (Deci\& Ryan, 1985; Ryan \&Deci, 2000) suggested that intrinsic and extrinsic motivation can be arranged on an internal-external continuum according to the individual's perception of relative autonomy. Motivations that involve a higher perception of autonomy are more internal and represent a higher quality of engagement. Intrinsic motivation is positioned on the internal end of the continuum, and represents a perception of full autonomy in engagement. "External regulation" lies on the external end of the continuum and describes the sense of coercion and external control that individuals experience when they engage in an undesirable task in order to avoid punishment or achieve rewards. Between these poles are three other types of extrinsic motivation that vary in level of perceived relative autonomy. Whereas most activities may not be intrinsically motivating, SDT proposes that people have an organismic tendency to internalize motivation for uninteresting and enjoyable activities. However, internalization is likely to occur only if the three psychological needs for competence, relatedness, and autonomy are satisfied.

\subsection{Empirical Basis of the Study}

Empirical basis of a research work can be defined as "research based on experimentation or observation. The word empirical means information gained by experience, observation, or experiment. The central theme in scientific method is that all evidence must be empirical which means it is based on evidence. In scientific method the word "empirical" refers to the use of working hypothesis that can be tested using observation and experiment. Empirical basis or evidence is information that justifies a belief in the truth or falsity of an empirical claim. In the empiricist view, one can only claim to have knowledge when one has a true belief based on empirical evidence.

In addition, an empirical basis of a research work is a way of gaining knowledge by means of direct and indirect observation or experience. Empirical evidence (the record of one's direct observations or experiences) can be analyzed quantitatively or qualitatively. Through quantifying the evidence or making sense of it in qualitative form, researchers can answer empirical questions, which should be clearly defined and answerable with the evidence collected (usually called data). Research design varies by field and by the question being investigated. Many researchers combine qualitative and quantitative forms of analysis to better answer questions which cannot be studied in laboratory settings, particularly in the social sciences and in education.

Uniquely, empirical basis of a research work has important objectives as follows:

- Goes beyond simply reporting observations.

- Promotes environment for improved understanding. 
- Combines extensive research with detailed case study.

- Proves relevancy of theory by working in a real-world environment (context).

Arguably, some of the reasons by which empirical research methods can be used are as follows:

- Traditional or superstitious knowledge has been trusted for too long.

- Empirical Research methods help integrating research and practice.

- Educational process or Instructional science needs to progress.

Moreover, the use of empirical basis or support in a research work/ study has the following advantages.

- Understands and responds more appropriately to dynamics of situations.

- Provides respect to contextual differences.

- Helps to build upon what is already known.

- Provides opportunity to meet standards of professional research.

In effect, the collection of evidence to prove or counter any theory involves planned research designs in order to collect empirical data. Several types of designs have been suggested and used by researchers. Also, accurate analysis of data using standard statistical methods remains critical in order to determine legitimacy of empirical research.

\subsection{Using Motivation to Sustain Female Students' Participation in ICT Practical Lessons}

Accordingly, Berliner (2008) is of the view that attribution theory describes the role of motivation in a person's success or failure in school situations. Success on a test, for instance, could be attributed to luck or hard work; the theory predicts the behavior of students depending on their responses. Students' motivation has been the concern of many educationists and educational psychologists. Motivating female students to become active participants in the classroom practical activities is believed to contribute toward achieving the aim of this research study.

According to Becta (2008), research study on the motivational effect of ICT showed that, 'both teachers and pupils believe ICT can motivate both boys and girls, albeit in different ways and to varying extents'. This lends credence to the fact that motivating females in the classroom in diverse ways could help to ensure their active participation and use of ICT tools in practical lessons.

Many people believe that males become motivated and succeed in the use of ICT tools more than females. This idea is confirmed in the statement below:

It was found that males seemed to be gaining more in certain cases, but females were not being disadvantaged. Passey (2004) suggest that ICT helps males move from a burst' pattern of working to a more persistent one - in other words, ICT can help males work more like females. However, the researchers of this study are of the view that motivating and encouraging female students will help to empower them in the use of ICT tools.

According to a study by Volman (2005), teachers believed that boys were motivated more by higher levels of access to ICT, and where ICT activities were competitive in nature and short in duration. A few teachers reported that girls need more support than boys in their use of ICT. This may however be due to the different approaches girls and boys take to working with ICT, rather than a lack of skills - a study from the Netherlands found that girls preferred to have an explanation before starting ICT activities, whereas boys would rather try things out for themselves.

Zimmermann \& Sprung (n.d.) presented the 'reasons why females seem to be reluctant to study computer science and shows a best practice example ...'

The research paper entitled "Technology is female: How girls can be motivated to learn programming and take up technical studies through adaptations of the curriculum, changes in didactics, and optimized interface design" sought to employ strategies to make technical subjects (contents) more appealing and motivating to both sexes.

Gender differences in academic interest and cognitive and interaction style are well documented. In particular, gender differences in motivation to learn science, technology, engineering, and math (STEM) have become more salient with recent concern about workforce imbalances in the fields of science and engineering.

Research conducted by Martin and Marsh (2000) on "motivating boys and motivating girls: does teacher gender really make a difference?" indicates that girls usually are not motivated since male teachers dominate the teaching profession in ICT and technical subjects.

Martin and Marsh explored the impact of student gender, teacher gender, and their interaction on academic motivation and engagement for 964 junior and middle high school students. According to the gender-stereotypic model, boys fare better academically in classes taught by males and girls fare better in classes taught by females. The genderinvariant model suggests that the academic motivation and engagement of boys and girls is the same for men and women teachers. Martin and Marsh also examined the relative contribution of student-, class-, and school-level

factors, finding that most variation was at the individual student level. Of the statistically significant main effects for gender, most favoured... Teachers therefore do not motivate students but rather create, through teaching opportunities that evoke motivation in the students. These opportunities would include making conditions as attractive and stimulating as possible and by matching tasking of students' ability. This is to emphasize that teachers do not need to motivate students from their own resources, but design the instruction that will motivate learners. Thus, motivating learners is not expensive as some educationists perceive it to be. Motivation in the school system includes; rewards, punishment, examination and information feedback on exercise, test, and assignment (Banahene, 2007).

Lier (1996) argues that 'IRF's (initiation response feedback) strict regulation and the asymmetry of the teacherstudent relationship embedded in its structure decreases students' motivation to contribute to classroom interaction'. This is to emphasize that a good student-teacher relationship must prevail in the classroom setting to ensure students' full participation in activities. To be able to achieve this, a number of strategies must be employed to motivate as well as giving the students free will to operate in the classroom with little or no restriction. 
In contrast with the literature reviewed on the above-mentioned subject, the researchers refused to address certain crucial issues notably gender differences in access and use, gendered digital divide, tertiary education and ICT, gender symbolism and feminist stand point theory.

By comparison, most of the literature on gender and ICT consider access by women to ICT. This includes concerns about infrastructure, training, local content and women in rural or underserved areas. Yet, to be in a position to benefit from the era of ICT, such as computer supported learning, both access and use of ICT are vital (Agbonlahor, 2005; Tinio, 2008). The problem however is the gendered digital divide (DD) as manifest in observed gender disparities in access as well as in use (Morahan-Martin 2000; Etta \& Elder, 2005). The gender and technology approach lead directly to the issue of meanings and values as they are created, defined and eventually attached to the use of ICT. (I the present researchers suspect that the processes of meaning and value creation, definition and assignment could also be gendered.)

\section{Methodology}

\subsection{Introduction}

This action research aimed at employing strategies to ensure female students' involvement and use of ICT tools in ICT practical/activity lessons in St. Joseph's and Berekum Colleges of Education in the BrongAhafo. Accordingly, Leedy (1993) stated that a method is a way of accomplishing an end result. A research methodology, therefore, refers to a set of methods, systems and procedures used in a particular research to achieve stated objectives. Additionally, the word method is coined from two Greek words: 'meth' and 'odos'. A method is therefore, following after the way someone found to be effective in solving a problem or reaching an objective or getting a job done. The meth means 'after' and 'odos' means 'way'. Thus, if the data is verbal, the methodology is qualitative; if the data is numerical, the methodology is quantitative hence this study employed a quantitative methodology.

This section of the study is paramount hence it is liable to affect the results and conclusions of the study. It considers the methodology and research design employed for the study.

\subsection{Research Design}

According to Grandhi (2004), "a research design is the tentative outline of a proposed research work". Kerlinger (1986) defines research design as "a plan structure and strategy of investigation so convinced as to obtain answers to research questions or problems". Similarly, a research design is a procedural plan that is adopted by a researcher to answer questions in a valid way, as a provisional outline of this action research, the researchers employed about six (6) strategies to determine the appropriate research design. The action research/ case study is mainly descriptive since it involves investigating, recording, analyzing and interpreting data.

According to Gerber (2009), "the aim of descriptive research is to verify formulated hypotheses that refer to the present situation in order to elucidate it". This method seeks to describe the phenomenal change that will be manifested when female students are motivated and encouraged to fully participate and use ICT tools in ICT.

\subsection{Research Population}

A research population is a group of individuals, persons, objects, or items from which samples are taken for measurement (Mugo, 2009). In this regard, the present researchers considered the teaching and learning situation in the schools which called for two categories of people who were directly involved. Students and teachers of St. Joseph's and Berekum Colleges of Education were therefore captured as the main population for the study. The choice of this population became necessary since it was hoped to provide the researchers with relevant and immediate data needed for the analysis.

\subsection{Sample and Sampling Procedure}

According to Grandhi (2004) "a complete coverage of the units of the universe selected for research, is not possible. Instead of complete coverage, selected units are studied". Lunsford and Lunsford (1995, p55), also defined sample as "a small subset of the population that has been chosen to be studied". Lunsford and Lunsford further cautioned that "the sample should represent the population and have sufficient size ....". Best and Kahn (1989) have observed that the primary aim of research is to discover principles that have universal application.

In this regard, the researchers saw that considering the entire population would not help; instead part of the population would be sampled to ensure reliability and validity of data collection. The sample for the study was made up of one hundred and twenty (120) female students who were in the said Colleges of Education level two hundred (200), and forty (40) teachers.

The simple random sampling method was used to select the sample. The said sample is probability in nature in which each member of the population had a known and equal chance of being chosen in the sample. The method helped the researchers to identify and enumerate the finite population. To avoid selection bias, it is

important to guarantee that each of the candidates for inclusion in the study has an equal opportunity for selection (Lunsford \& Lunsford, 1995).

Stratified sampling technique was also adopted alongside the random sampling since the study concerned the inclusion of gender group (female students) in ICT. According to Lunsford and Lunsford (1995), stratified sampling is "a method by which subjects are grouped according to strata such as age, gender or diagnosis. Using this method, subgroups of interest could be defined and ... sampled for each group". 
The said subgroup included seventy five percent (75\%) female students and twenty five percent (25\%) teachers who were used for the study.

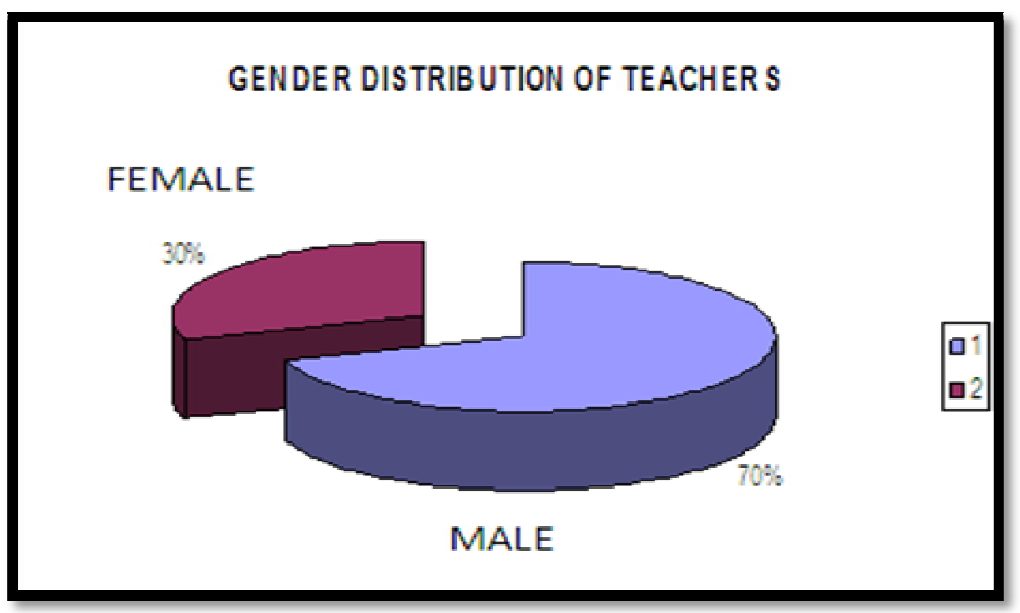

Figure 1: Gender Distribution of Teachers

\subsection{Instrumentation}

Research techniques refer to the methods for gathering reliable information to answer a question or support an experimental hypothesis (Okai, 2009). In view of this, the researchers of this study employed questionnaire technique to gather valid and reliable data in aid of rectifying the situation at hand. It must be emphasized here that good data is directly related to the questions; that is, they provide direct answers (Padak\&Padak, 2009).

According to Cohen, Manion and Morrison (2003), questionnaires can provide a structured and straightforward analysis of information. Moreover, questionnaires are relatively more economical than other approaches in terms of time and money and they can be convenient for respondents as they can complete them in their own time.

Questionnaire is usually more superficial than the interview. It is usually used in group work. The questionnaire is especially useful to obtain information about reasonably big groups. Questionnaire is usually characterized by relatively low cost, ease of interpreting information, and likelihood of answering each question.

\subsection{Data Collection Procedure}

The present researchers therefore sat down to carefully plan, design and administer one hundred and sixty (160) questionnaires to respondents (female students and teachers) to obtain information on the topic under discussion. These questionnaires were presented to the respondents during the data collection stage of the study. The items in the questionnaires were written in clear language to enable respondents understand and answer the questions objectively as possible. The choice of the questionnaire technique for the study was that many respondents could be reached within a short period of time. Respondents were expected to answer every item in the questionnaire. It also required little time of respondents. Some examples of sample items on the questionnaire included 'I am regular at ICT practical lessons', 'I feel happy and satisfied in ICT class', 'Practice makes man perfect', etc.

In addition, the respondents were given little opportunity to express their views as they were restricted to the questions and their corresponding answers. The main items contained in the questionnaire included how motivation can add value to female students' participation in ICT practical lessons; what teachers can do to develop female students' interest in ICT lessons and finally relationship between practical learning and students' performance.

\subsection{Intervention Design and Implementation}

This aspect of the study presents the actual measures were taken to alleviate the problem understudy. To intervene means "to become involved, intentionally, in a difficult situation in order to improve it or prevent it from getting worse". The researchers, after considering existing literature on the problem, came out with six (6) interventional strategies and their implementation which contributed to overcoming the challenges.

\subsection{Intervention Design}

Classroom research/ Case study focuses on identifying or evaluating the "method in our madness" as it affects our students' learning. As classroom teacher who has been teaching ICT at St. Joseph's College of Education since 2009 academic year, and attending certain academic programs in Berekum College of Education as well, a number of challenges that affect female students' learning and academic performance have been observed. The involvement and improvement in the use of technological equipment (ICT tools) among female students has become unease. The researchers of this study observed similar situation even among his university female counterparts during the period of study at the university.

Encouraging females' participation and improvement in practical lessons in ICT through motivation and attractive techniques was hoped to alleviate the fear and nervousness and equip them with the skills of using modern technology. To do this, the researchers proposed the following interventional designs and mechanisms to effect a change in female students' attitude towards practical lessons in ICT. 
- Motivational techniques

- Good teacher-student relationship

- A talk on career opportunities in ICT

- Applying a variety of teaching methods

- Provision of guidance and counseling

- Maintaining good attitude of students and teachers towards ICT

\subsection{Intervention Implementation}

The following describe how the intervention designs enumerated above were implemented in solving the problem.

\subsection{Motivational Techniques}

The researchers upon considering Abraham Maslow's theory of need hierarchy saw the essence of using a variety of motivational strategies to improve females' participation and improvement in practical exercises in ICT. These need hierarchy include:

- Physiological Needs

- Safety needs

- Love and belongingness needs

- Esteem needs

- Need for self-actualization (Maslow, 1954).

In view of this, the researchers ensured that the computer laboratory which was mainly used for practical activities was safe for students and all users. Students particularly females who came to the laboratory were assisted to overcome the problem of psychological, safety, affection and self-actualization, as these are the core of Maslow's theory. In addition, verbal praise, privileges and good grades as incentives were also adopted to motivate students. As a basic principle of motivation, according to Weller (2005) "incentives which include privileges and receiving praise from the instructor are likely to motivate an individual at a particular time. The instructor must therefore determine an incentive that is appropriate at each instance". In all these, students who excelled, showed interest, participated regularly in ICT practical activities were given the motivational packages and encouraged to progress. Those who performed poorly were not neglected, they were assisted and encouraged to do better next time.

\subsection{Good Teacher-Student Relationship}

In order to enhance friendly and free communication atmosphere for effective teaching and learning, the researchers managed to create good rapport with his students. Female students who had difficulties in ICT one way or the other felt free to approach the teacher for assistance. Interestingly, most of the female students confronted the researchers with their computer problems in the house while others

sought for computer programs. In doing this, the researchers were very cautious in order not to be biased in such classroom relationships since it was aimed at improving performance and not mere social satisfaction.

\subsection{Applying a Variety of Instructional Methods}

According to Sarfo (2007), instructional strategy is the teacher's approach to using information, selecting resources, and defining the roles of students. In view of this literature, the researchers used varied teaching methods in the presentation of ICT lessons both in the computer laboratory and classroom. The researchers used discussion and demonstration methods, relevant teaching and learning materials, and further activity and practice to enhance students' understanding of the concepts. The researchers put students into small groups to work on activities, problems and exercises. The use of small groups helped the female students to share, participate and perform better in the subject. Again, the researchers used interactive participatory and learner-centered methods such as activity, questions and answers to create an active learning environment as emphasized by Needham and Hill $(1987$, p8) that "... learning is an active, not a passive process". A lot of exercises were given and marked instantly and the results discussed for improvement of performance.

\subsection{A Talk on Career Opportunities in ICT}

The researchers were aware that most students did not have any idea on career opportunities in ICT. Casually, when students were asked to mention some ICT career opportunities known to them, their responses were only Internet café operator and typist. The researchers upon consultation with school authorities organized a talk on career opportunities in ICT. Resource personnel including renowned ICT gurus, old students and some ICT professionals were invited to help female students know why they needed to take ICT seriously. Colleges of Education online registration for admissions and semester examinations, WAEC online registration for examination and result checker, workers particularly females in the banks and other industries were used as examples to help female students appreciate the study of ICT. According to Brickman (2008), "the basic principle of career counselling and guidance is that a person is better equipped to make occupational plans after determining his or her own characteristics, examining the requirements of various occupations, and matching the two sets of facts with the aid of a skilled counselor". 


\subsection{Provision of Guidance and Counselling}

According to Assoah (2008), some objectives of guidance and counselling for teachers and students are "to understand better the individuality of each student for whom they are responsible and to develop learning or study skills and values", respectively. The researchers, having observed that guidance and counselling section in the schools, which was endowed with trained and experienced personnel, could be

useful in dealing with the problem at stake. The guidance and counselling coordinators were invited from time to time to ensure proper guidance for female students in studying ICT.

\subsection{Maintaining Good Attitude of Teachers and Students towards ICT in the Schools}

The Adentwi's quotation on role model states, "set it down to thyself, as well to create good precedence as to follow them" (Bacon, 1561 - 1626 in Adentwi, 2009). The researchers considered the need to take advantage of teachers' fundamental role as role model to promote positive attitude towards the study of ICT. In doing this, the researchers maintained good rapport between the teachers in the school. Teachers who used to show interest in learning computing were assisted to do so. The computer laboratory was also opened to all teachers who had the desire to use computer. By and large, all these female students got to know that ICT was very important since almost all teachers were willing to learn and use the computer. Teachers were advised during staff meetings to release students as soon as possible when it was time for ICT lessons. After implementing the interventions, female students' attitude towards ICT practical activities was improved tremendously. In general, the interventions employed in this research have had a great impact on female students' participation and improvement in ICT practical activities.

\subsection{Data Analysis}

Analysis according to Adentwi (2009) is "the examination of something in detail in order to understand it better or draw conclusions from it".

Data analysis involves examination of the data in the order in which your questions have been answered. If you have asked more than one question, you will want to sort the data according to the question. And you may want to discard (or at least set aside) data that do not directly relate to the questions you have posed.

In an effort to make the presentation of the findings comprehensive and readable, the collected data were organized into frequency distribution tables for easy interpretation and analysis of results. Tables were used because they could easily be generated using tools like Ms Excel or statistical package for social sciences (SPSS) and they are also easily understood. This helped the researchers to make meaningful conclusions for the study. Specifically, the statistical test employed in this study was statistical package for social sciences (SPSS) for the interpretation and analysis of the results obtained.

\section{Data Analysis and Results}

\subsection{Introduction}

This chapter focuses on the presentation and analysis of data gathered from the field. The results have been presented under the various themes shown in the research question. Information has been presented using frequency tables.

\subsection{What Motivation can do to Sustain Female Students' Participation in ICT Practical Lessons?}

Table 1 shows students' responses when they were asked to indicate whether they feel happy and satisfied in ICT class. They were to choose one of the following options: 'very true of me', 'true of me' and 'not true of me'. 44 (i.e. $36.7 \%$ ) of them chose very true of me,59 (i.e. $49.2 \%$ ) of them chose true of me and 17 (i.e. $14.2 \%$ ) also chose not true of me.

It is evident from the table that students feel happy and satisfied in ICT class. The relevance of this finding shows students appreciated the fact that the provision of warm and accepting yet business-like atmospheres, has enabled them promote persistent effort and favorable attitudes toward learning.

\begin{tabular}{|c|c|c|}
\hline Responses & Frequency & Percentage \\
\hline Very true of me & 44 & 36.7 \\
True of me & 59 & 49.2 \\
Not true of me & 17 & 14.2 \\
\hline Total & 120 & 100.0 \\
\hline
\end{tabular}

Table 1: Students' Happiness and Satisfaction in ICT Class

Source: Field Work July, 2018 (SPSS V16.0)

When asked about three things teachers do to increase learners' interest in class, 21 (i.e. 52.2\%) of the respondents indicated practical demonstration, good teaching method and motivation. 14 (i.e. 35\%) of them indicated healthy relation with students, incentives and regularity at class while 5 (i.e. 12.5\%) of the respondents indicated role model, punctuality and good counselling

It is evident from table 2 that teachers really increase learners' interest during teaching and learning process. The relevance of this finding shows that students appreciated the fact that teachers do all what is expected of them to make 
them (students) show interest in class When asked about three other things that activate students to be interested in ICT in general, 60 (i.e. 50\%) of them said job opportunities, self tutorial and practical work; 49 (i.e. 40.8\%) of them also indicated source of entertainment, motivation and role model while 11 (i.e. 9.2) of the respondents indicated enhancing understanding, interesting and source of entertainment.

As indicated in table 3, ICT in its entirety can have positive impact on students' learning. The relevance of this finding indicates that students believed ICT use could offer them effective understanding, interest and source of entertainment in learning.

\begin{tabular}{|c|c|c|}
\hline Responses & Frequency & Percentage \\
\hline Job opportunity, self & 60 & 50.0 \\
tutorial, practical work & 49 & 40.8 \\
Source of entertainment, & 11 & 9.2 \\
motivation, role model & & \\
Enhancing understanding, & & \\
interesting, source of & & \\
information & & 100.0 \\
\hline Total & 120 & \\
\hline
\end{tabular}

Table 2: Three Other Things That Make Students Show Interest in ICT in General Source: Field Work July, 2018 (SPSS V16.0)

When asked about three things teachers do to increase learners' interest in class, 21 (i.e. 52.2\%) of the respondents indicated practical demonstration, good teaching method and motivation. 14 (i.e. 35\%) of them indicated healthy relation with students, incentives and regularity at class while 5 (i.e. 12.5\%) of the respondents indicated role model, punctuality and good counseling It is evident from table 3 that teachers really increase learners' interest during teaching and learning process. The relevance of this finding shows that students appreciated the fact that teachers do all what is expected of them to make them (students) show interest in class

\begin{tabular}{|c|c|c|}
\hline Responses & Frequency & Percentage \\
\hline $\begin{array}{c}\text { Practical demonstration, } \\
\text { good methodology, } \\
\text { motivation }\end{array}$ & 21 & 52.5 \\
$\begin{array}{c}\text { Healthy relation with } \\
\text { students, incentives, } \\
\text { regularity at class } \\
\text { Role model, punctuality, } \\
\text { good counselling }\end{array}$ & 14 & 35.0 \\
Total & 5 & 12.5 \\
\hline
\end{tabular}

Table 3: Three Things Teachers do to Increase Learners' Interest in Class

Source: Field Work July, 2018 (SPSS V16.0)

When asked about three things teachers do to reduce learners' interest in class, 24 (i.e. 20\%) of the respondents indicated lack of motivation, insufficient practice, lateness; 60 (i.e. 50\%) of them indicated reprimand, punishment and irregularity or absence in class while 36 (i.e. 30\%) of them also indicated lecture method, teaching without TLMs and discrimination.

Clearly, it is evident from table 4 that learners' interest in teaching and learning can be reduced by teachers. The relevance of this finding shows students believed that teachers sometimes apply extrinsic motivation (punishment, reprimand, etc.) to shape them in the teaching and learning process.

\begin{tabular}{|c|c|c|}
\hline Responses & Frequency & Percentage \\
\hline Lack of motivation, & 24 & 20.0 \\
insufficient practice, & 60 & 50.0 \\
teachers' absence & 36 & 30.0 \\
Teachers' reprimand, & & \\
punishment, teachers' & & \\
lateness & & \\
Lecture method, & & \\
teaching without, & & \\
appropriate TLMs, \\
discrimination & & 100.0 \\
\hline Total & 120 & \\
\hline
\end{tabular}

Table 4: Three Things Teachers do to Reduce Learners' Interest in Class Source: Field Work July, 2018 (SPSS V16.0) 


\section{Conclusion} lessons?

The purpose of this study was How can motivation help sustain female students' participation in ICT practical

\subsection{Using Motivation to Sustain Female Students' Participation in ICT Practical Lessons}

The research question investigated how motivation could help sustain female students' participation in ICT practical lessons. To address that question, students were asked to report about their regularity at ICT practical lessons. All the students used for the research reported that use of motivation in education could increase students' regularity at lessons to a large extent. A majority of students perceive motivation to offer advantages to classroom learning but only few also struggle to see specific benefits associated with it. Thus, when used properly gives students the drive to be committed to whatever that happens in the teaching and learning environment. The way students feel about a program influences their commitment to it. For instance, if students feel secured, respected, esteemed, and empowered, they are likely to make a strong effort. Again, the students admitted that motivation could increase their seriousness in class. Students have varying perceptions about effectiveness of motivation when used in ICT practical environment, but the findings in this study show that majority of the students thought motivation could really enhance students' regularity in teaching. In addition, some students reported that they would like to go to class regularly to practice what they had been taught to sharpen their skills. The results from this study confirm definitions of motivation by some researchers as indicated in the literature review. The reason surrounding definition of motivation here stemmed from the fact that the first question looked at how motivation could increase students' regularity at ICT practical lessons and motivation as a whole must be defined to indicate its effect on students' regularity Eisenberg (2010) defined motivation as the act of giving somebody a reason or incentive to do something.

Eccles and Wigfield (2002) further described motivation as the cause of an organism's behaviour, or the reason that an organism carries out some activity which involves both conscious and unconscious drives.

On the contrary, a fraction of students did notagree about being motivated to be regular at ICT practical lessons. The present study indicates that majority of the students believed that motivation enhanced their regularity at lessons in ICT. An extensive research review by Conner (2007) is of the view that teaching and learning process should be designed to make the learner feel secured and empowered to undertake any activity in the school programme. Such an activity comes from rewards inherent to a task or activity itself - the enjoyment of a puzzle or the love of playing basketball, for example. One is saidto be intrinsically motivated when engaging in an activity with no apparent reward except for the activity itself. In affirmation, students are likely to be intrinsically motivated if they: attribute their educational results to internal factors that they can control (e.g. the amount of effort they put in), believe they can be effective agents in reaching desired goals (i.e. the results are not determined by luck), are interested in mastering a topic, rather than just rote-learning to achieve good grades.

Few students also feared that to a small extent the use of motivation in education would adversely affect students' seriousness in class. These students perhaps believed that students might not be regular when they see the activity to be performed unrewarding and this might affect their regularity at lessons in ICT.

Frankly, motivation of students is the surest way to guarantee their regularity at lessons. Students' motivation has been found to be a major predictor of regularity at instructional settings (Banahene, 2009).

Again, motivation directs an individual towards certain goals. This means that the choice people make is greatly influenced by motivation. Motivation promotes initiation of certain activities and persistence in those activities. Similarly, motivation affects the learning strategy and cognitive processes an individual employ. It increases the likelihood that people will pay attention to something, study and practice it, and try to learn in a meaningful fashion.

Simons (1987) also accepted the fact that motivation theory has influenced a number of different fields, including education. This wide influence is due in part to the high level of practicality of Maslow's theory.

\section{References}
i. Allen, D. (ed) (1974). Instruction. In Malvin L. B. The Philosophy for Quality
ii. Vocational Education Programs.Washington, DC: American Vocational
iii. Association
iv. Adentwi, K.I. (2009). Psychology of Human Development. Kumasi: Biraa Press.
v. pp. $22-40$
vi. Archer, F. (2003). Measurement and evaluation in education. Kumasi: PAKS
vii. Publications, pp. 13
viii. Asiedu-Addo, S. (2008).Encourage females to study technical subjects.
ix. Junior Graphic.pp. 3.
x. Assoah, S. K. (2008). Guidance \& counselling in education. Kumasi: Biraa Press.
xi. pp. 10
xii. Abdulla, Y. \&Twizell, EH. (2008). Higher Education in the 21st Century: Issues and Challenges.London, Taylor \& Francis Group, UK.
xiii. Bacon, F. (2008).Set it down to thyself, as well to create good precedents as to follow them. In Microsoft Encarta Student 2009 [DVD].Washington Redmond:
xiv. Microsoft Corporation
xv. Becta (2008). How do boys and girls differ in their use of ICT? - Research report
xvi. Retrieved July 18 2018, from http:/ / partners.becta.org.uk/ uploaddir/ 
xvii. Ben-Jacob, M. G. (2005). Integrating computer ethics across the curriculum:

xviii. A case study, Educational Technology \& Society, pp. 198-204.

xix. Berliner, D. C. (2008).Educational psychology.In Microsoft Encarta Student 2009

xx. [DVD]. Redmond, WA: Microsoft Corporation.

xxi. Brause, R. S. \&Mayher, J. S. (Ed.) (1994).Search and re-search: what the inquiring teacher needs to know. United Kingdom: The Falmer Press, Rankine

xxii. Road Basingstoke, Hamsphire RG24 OPR87

xxiii. Broussard, S. C., \& Garrison, M. E. B. (2004).The relationship between classroom motivation and academic achievement in elementary school-aged children.

xxiv. Family and Consumer Sciences Research Journal, 33(2), 106-120.

xxv. Brickman, W. W. (2008).Vocational education.In Microsoft Student 2009 [DVD].

xxvi. Redmond, WA: Microsoft Corporation.

xxvii. Brundtland, G. H. (2002). World Health Organization (WHO) Director-general's executive statement on gender policy: Integrating Gender Perspectives I the Work of WHO.

xxviii. Clark, R.C \& Mayer, R.E. (2003).e-Learning and the science of Instruction: proven guidelines for consumers and designers multimedia learning.

xxix. San Francisco: Pfeiffer

xxx. Cradler, J., McNabb, M., Freeman, M. \& Burchett, R. (2002).How does technology influence student learning. Retrieved March 15, 2018, available at:

xxxi. http:/ / caret.iste.org/ caretadmin/ news documents/ StudentLearning.pdf.

xxxii. Conner, M. L. (2007). A primer on educational psychology. Retrieved February 18,

xxxiii. 2009, available at: http:/ / agelesslearner.com

xxxiv. Deci, E. L. \& Ryan, R. M. (1985).Intrinsic motivation and self-determination in

xxxv. Human behavior. New York: Plenum. ISBN 0-30-642022-8.

xxxvi. Derbyshire, H. (2003). Gender issues in the use of computers in education in Africa,

xxxvii. DFID: 73

xxxviii. Deci, E. L. (1971). Effects of externally mediated rewards on intrinsic motivation.

xxxix. Journal of Personality and Social Psychology, 18, 105-115.

xl. Eisenberg, N. (2010). Self-regulation and school readiness. Early Education and

xli. Development, 21(5), 681-698.

xlii. Eccles, J., Midgley, C., and Wigfield, A., (1993). Development during adolescence:

xliii. The impact of stage-environment fit on young adolescents' experiences in schools and families. American Psychologist, 48, 90-101.

xliv. Eisenberger, R., \& Cameron, J. (1996).Detrimental effects of reward: Reality or myth? American Psychologist, 51, 1153-1166.

xlv. Entwistle, N.J (general editor) (1990).Handbook of educational ideas and practices.

xlvi. London and New York: Routledge pp. 144.88

xlvii. Fuglestad, A. B. (2005). Students' use of ict tools - choices and reasons. In Chick, H. L.\& Vincent, J. L. (eds.) Proceedings of the 29th conference of the international group for the psychology of mathematics education.

xlviii. Melbourne: PME, AgderUniversity College Vol. 3, pp. 1-8.

xlix. Guay, F. (2010).Intrinsic, identified, and controlled types of motivation for school subjects in young elementary school children. British Journal of

1. Educational Psychology, 80(4), 711-735.

li. Gerber, R. (2009). Research skills:Centre for Teaching, Learning and Media. Nelson

lii. Mandela Metropolitan University. Retrieved March 15, 2018 from

liii. http:/ / www.petech.ac.za/ robert/ research.html

liv. Grandhi, N. (2004). Introduction to research methodology, Block 1. National Open

lv. University, School of Social Sciences.

lvi. Grubb, W.N., Lazerson, M. (2005).Vocationalism in Higher Education: The Triumph of the Education Gospel.

lvii. Garrison, D.R \& Anderson, T. (2003).E-learning in the 21sth century- A framework for research and practice. New York and London, Routledgefalmer.

lviii. Greer, L. (2001). Does changing of Method of Assessment of a Module Improve the

lix. Performance of a Student.Assessment and Evaluation in Higher Education.

lx. 26(2)

lxi. Hafkin, N. \& Taggart, N. (2001).Gender, information technology, and developing countries: An Analytic Study. Washington: USAID Retrieved April

lxii. 17, 2009 from http:// www.usaid.gov/ wid/ pubs/it01.htm

lxiii. Hyde, J. S., \& Kling, K. C. (2001).Women, motivation, and achievement.In

lxiv. Psychology of Women Quarterly, 25, pp. 364-378

lxv. Haynie, W.J. III (2003) Gender issues in technology education: A Quasi-

lxvi. Ethnographic Interview Approach.In Journal of Technology Education

lxvii. Vol. 15 No. 1, Fall2003

lxviii. Hornung-Prahauserm, R. M. V, Eliane S. (2005).Inclusion of females in ICT - A lifelong learning challenge for changeagents: Benefits of innovative e-learning tools and training methods. Retrieved March 10, 2018, from 
lxix. http:/ / www.salzburgresearch.at/ research gfx/ eden proict 2005.pdf

lxx. Harter, S. (1981).A new self-report scale of intrinsic versus extrinsic orientation in the classroom: Motivational and informational components. Developmental

lxxi. Psychology, 17, 300-312.

lxxii. Harter, S. (1992).The relationship between perceived competence, affect, and motivational orientation within the classroom:Processes and patterns of change. In A. K.

lxxiii. Johnson, K. (2003). Telecentres and the gender dimension: an examination of how

lxxiv. engenderedtelecentres are diffused in Africa. Georgetown: Unpublished

lxxv. MSc thesis, Georgetown University.

lxxvi. KNUST (2009).Admission brochures for 2009/ 2010 academic year. Kumasi: Kwame

lxxvii. Nkrumah University of Science and Technology. Retrieved February 07,

lxxviii. 2009, from http:/ / admissions.knust.edu.gh

lxxix. Leedy, P. D. (1985). Practical research: planning and design. (3rded.). New

lxxx. York: McMillan Publishing Co.

lxxxi. Lunsford, T. R. \& Lunsford, B. R. (1995). Research forum--the research sample, part

lxxxii. I: sampling,In Journal of Orthotists and Prosthetists, America Academy of

lxxxiii. Orthotists and Prosthetists. Retrieved May 13, 2018, from

lxxxiv. http:/ / www.oandp.org/jpo/ library/ index/ 1995 03.asp. pp. 105-112

lxxxv. Leuven, Z. (2004). Reading Behaviour in the digital environment:changes in

lxxxvi. Reading behaviour over the last 10 years. J. Doc, 61 (6): 700-12

lxxxvii. Macueve, G., Mandlate, J., Ginger, L., Gaster, P. \&Macome, E. (2009).Women's use

lxxxviii. of information and communication technologies in Mozambique: a tool for empowerment? pp. 22

lxxxix. Martin, A. \& Marsh, H. (2005).Motivation of girls' research article. In Australian

xc. Journal of Education (2009) Motivating boys and motivating girls: does teacher gender really make a difference? .

xci. Maslow, A. H. (1943). A theory of human motivation. Psychological Review, 50, pp.

xcii. 370-396

xciii. Millar, J. \&Jagger, N. (2001).Women in ITEC Courses and Careers. Brighton, UK:

xciv. University of Sussex. pp. 40-50. Retrieved March 10, 2018, from

xcv. http:// www.womenandequalityunit.gov.uk/ research/pubn 2001.html

xcvi. Mitter, S. (2007).Globalization and ICT: Employment Opportunities for Women Part III.

xcvii. Mugo, F. W. (2009). Sampling in research. London: Chapman \& Hall. pp. 169-184.

xcviii. Maslow, A. (1954). Motivation and personality. New York: Harper.

xcix. Margolis, J. \& Fisher, A. (2002).Unlocking the clubhouse: Women in Computing MIT Press

c. Nobel, C. (2007). Back to school: getting girls into IT. In InfoWorld.29 January,

ci. Retrieved March 10, 2018, from www.infoworld.com/article/ 07/ 01/ 29/ 05FEwomentechteen_1.html

cii. Nulden, U. (1998). The Excon Project: Advocating Continuous Examination. The SIGSCE Technical symposium on Computer Science Education, Atlanta, USA, ACM Press

ciii. Needham, R \& Hill, P. (1987).Teaching strategies for developing understanding in science; Children's Learning in Science Project. Leeds: University of Leeds, LS2 9JT.

civ. OECD/ European Communities (2004).Career guidance: a handbook for policy makers. France Paris: OECD Publications, 2. Retrieved March 25, 2018 from http:/ / www.oecd.org/ dataoecd/ 53/ 53/ 34 060761.pdf

cv. Omamo, S. A. (2009). Reflections on the mentoring experiences of ICT career women in Nairobi, Kenya: looking in the mirror. In The International Development Research Centre (IDRC). pp. 19 of 22

cvi. Owusu-Banahene, N. O. (2007). Educational psychology: The science of learning. Kumasi: Narco Printing Works, KNUST, pp. 222-231.

cvii. Padak, N. \&Padak, G. (2009).Research to practice: guidelines for planning action research projects. In Ohio Literacy Resource Center. Retrieved 15, 2009, from http:/ / literacy.kent.edu/ Oasis/ Pubs/ 0200-08.htm

cviii. Pamela J. S. \& Stephenson, R. (2008).Giving and getting career advice: a guide for junior and senior faculty. Retrieved March 29, 2018, from http:/ / sitemaker.umich.edu / advance

cix. Passey, D. (2004). The motivational effect of ICT on pupils - research report RR523. DfES. In Becta (2008) How do boys and girls differ in their use of ICT? Retrieved July 18, 2018, from http:/ / partners.becta.org.uk/ uploaddir/ downloads / page documents/ research/ gender ict briefing.pdf

cx. Payton, F., L. Kvasny, V. M. \&Amadi, A. (2007).Gendered perspectives on the digital divide IT education and workforce. Proceedings of the $9^{\text {th }}$ International Conference on Social Implications of Computers in

cxi. Developing Countries, São Paulo.

cxii. Pintrich, P. R., \&Schunk, D. (2002).Motivation in education: Theory, research and applications (2nd ed.). Upper Saddle River, NJ: Prentice-Hall.

cxiii. Robin, A. (1997). Policy and practice in primary education local initiative: National

cxiv. Agenda (2nd ed). London: Routledge, EC4P 4EE 11 New Fetter Lane.

cxv. Ryan, R. M., \&Deci, E. L. (2000).Self-determination theory and the facilitation intrinsic motivation, social development, and well-being. American

cxvi. Psychologist, 55, 68-78.

cxvii. Rogers, C. (1963). The actualizing tendency in relation to "motives" and toconsciousness. In M. R. Jones (Ed.), Nebraska symposium on motivation 
cxviii. (Vol11, pp. 1-24). Lincoln, NE: University of Nebraska Press.

cxix. Skinner, B. F. (1953). Science and human behavior. New York: Macmillan.

cxx. Samman, T. (2008).Promoting ICT among young women in Europe. In Microsoft

cxxi. Corporate Affairs. Retrieved March 29, 2018, from

cxxii. http:/ / www.buildaskill.com/ blog/ category/ editorials/ commentary

cxxiii. Sarfo, F. K. (2007). Educational technology; instructional technology. Kumasi: Ospra

cxxiv. Publishing Company Limited, pp. 118, 128.

cxxv. Sarfo, F.K. (2009). Practice (learning method).Kumasi: Ospra Publishing Company

cxxvi. Limited, pp. 130, 152.

cxxvii. Shackelford, R. (2006). Computing curricula 2005: The overview report, the

cxxviii. association for computing machinery (ACM), the association for

cxxix. information systems (AIS), the computer society (IEEE-CS).Retrieved March

cxxx. 25, 2018 from http:/ / www.acm.org/ education/ curric vols/ CC2005-

cxxxi. March06Final.pdf

cxxxii. Sharma, U. (2003). Women's empowerment through information technology, New Delhi:Authors' Press.92

cxxxiii. Shin, H. K. (2004, October 1). Using technology to guide the learning of declarative knowledge. In ITE teachers' conference: Reflective practitioners in action.

cxxxiv. Singapore: institute of technical education

cxxxv. Simons, J. A., Irwin, D. B. \&Drinnien, B. A. (1987).Psychology - the search for understanding. New York: West Publishing Company. Retrieved February

cxxxvi. 18, 2009, frhttp:/ / honolulu.hawaii.edu/ intranet/ committees/ FacDevCom/

cxxxvii. guidebk/ teachtip/ maslow.htm

cxxxviii. Stephen, A. (2006). Communication technologies and women's empowerment. New

cxxxix. Delhi: Rajat. Ghana. Ministry of Education Science and Sports (2004).Teaching syllabus for information and communications technology (College of Education). Accra: Ministry of Education Science and Sports, pp. ii

cxl. Van Lier, L. (1996). Interaction in the language curriculum: awareness, autonomy and authenticity. London: Longman. Ghana. WAEC (2008). Online registration, West African Examination Council. Retrieved March 29, 2018, from http:/ / www.waecdirect.org

cxli. Weller, M. (2005).General principles of motivation. In Los Angeles Business Journal.

cxlii. White, R. W. (1959). Motivation reconsidered: The concept of competence. Psychological Review, 66, 297-333.

cxliii. Zimmermann, L. \& Sprung, G. (n.d.) Technology is female: How girls can be motivated to learn programming and take up technical studies through adaptations of the curriculum, changes in didactics, and optimize interface design. Graz,AUSTRIA: AltePoststr. 149, 8020. Retrieved July18, 2018, from http:/ / icee2008hungary.net/ download/ fullp/ full_papers/ full_paper454.pdf 